\title{
Pengaruh Pemberian Kalsium Terhadap Penurunan Tekanan Darah Ibu Hamil Dengan Riwayat Preeklampsi
}

\author{
Meldawati \\ Profesi Kebidanan, Universitas Sari Mulia \\ Provinsi Kalimantan Selatan \\ E-mail:meldawatialbar05@gmail.com
}

DOI: $\underline{10.33859 / \text { dksm.v11i1.581 }}$

\begin{abstract}
Abstrak
Latar belakang: Preeklampsia adalah suatu sindrom spesifik pada kehamilan dengan gejala klinis berupa penurunan perfusi organ akibat vasospasme dan aktivasi endotel

Tujuan : penelitian ini adalah untuk mengetahui perubahan tekanan darah pada ibu hamil dengan riwayat preeklampsi sebelum dan setelah pemberian kalsium selama 8 minggu dengan dosis $3 \times 500$ $\mathrm{mg} /$ hari

Metode : Penelitian ini menggunakan metode desain quasi eksperimental dengan rancangan pre-post test. Tehnik pengambilan sampel adalah Purposive sampel yaitu $30 \mathrm{ibu}$ hamil.Analisis data menggunakan analisis univariat dan bivariat dengan uji Paired T Test

Hasil : Berdasarkan hasil penelitian menunjukkan bahwa terdapat penurunan tekanan darah sebelum dan setelah pemberian kalsium dengan uji Paired T test di peroleh $p$ Value $.000<0.05$ artinya signifikan.

Kesimpulan : pemberian kalsium menurunkan tekanan darah ibu hamil dengan riwayat preeklampsi

Kata kunci: Riwayat Preeklampsi, Kalsium, Tekanan Darah
\end{abstract}

\section{Abstract}

Background: Preeclampsia is a specific syndrome in pregnancy with clinical symptoms of reduced organ perfusion due to vasospasm and endothelial activation

Objective: The purpose of this study was to determine changes in blood pressure and electrolyte levels in pregnant women with a history of preeclampsia before and after the administration of calcium for 8 weeks at a dose of $3 \times 500 \mathrm{mg} /$ day

.Method: This study used a quasi-experimental design method with a pre-post test design. The sampling technique is a Purposive sample, which is 30 pregnant women. Data analysis uses univariate and bivariate analysis with Paired T-Test.

Results: The results showed that there was a decrease in blood pressure before and after administration of calcium with the Paired T-test obtained pValue $000<0.05$ meaning significantConclusion: It was concluded that calcium reduced the blood pressure of pregnant women with preeclampsia,

Keywords: History of Preeklampsi, Calcium, Blood Pressure, Electrolytes 
Dinamika Kesehatan Jurnal Kebidanan dan Keperawatan Vol 11 No. 1 Juli 2020 ( ISSN: 2086-3454 EISSN: 2549-4058) url: http://ojs.dinamikakesehatan.unism.ac.id DOI : https://doi.org/10.33859/dksm.v11i1

Pengaruh Pemberian Kalsium Terhadap Penurunan Tekanan Darah Ibu Hamil Dengan Riwayat Preeklampsi

\section{PENDAHULUAN}

Preeklampsia adalah suatu sindrom spesifik pada kehamilan dengan gejala klinis berupa penurunan perfusi organ akibat vasospasme dan aktivasi endotel. Preeklamsia hingga saat ini masih merupakan komplikasi serius dalam kehamilan dan patofisiologinya masih belum diketahui dengan pasti, namun tanda-tandanya dapat diketahui dengan adanya peningkatan TD, proteinurine dan edema(Kartika,2016). World Health Organisation (WHO)(2013), menunjukkan, di seluruh dunia sekitar 982 juta orang atau 26,4\% ibu hamil mengidap hipertensi dengan perbandingan $26,6 \%$ pria dan $26,1 \%$ wanita. Angka ini kemungkinan meningkat menjadi 29,2\% ditahun 2025(Purnasari, Briawan and Dwiriani, 2016) .

Angka insiden preeklamsia di seluruh dunia berkisar antara 3\% hingga 14\% dari seluruh kehamilan Belum ada bukti yang menyatakan adanya perubahan terhadap jumlah tersebut setidaknya dalam sepuluh tahun terakhir. Preeklampsia merupakan penyebab utama morbiditas dan mortalitas maternal di daerah berkembang, serta menyebabkan peningkatan hingga 5 kali mortalitas perinatal. Di dunia, 50.000 - 70.000 wanita meninggal tiap tahunnya akibat preeklampsia dan eklampsia. WHO memperkirakan kasus preeklampsi tujuh kali lebih tinggi di negara berkembang dari pada di negara maju. Rendahnya prevalensi di negara maju antara 1,3\%-6\% dibandingkan yang terjadi di negara berkembang yaitu 1,8\%-18\% menunjukkan ada sisi dari preeklampsi mampu kita cegah dalam manajemen pelayanan kesehatan.

Insiden preeklampsi di indonesia sendiri adalah 123.273/tahun atau sekitar 5,3\%. Kematian ibu oleh karena preeklampsi lebih dirasakan di negara berkembang berkisar $10-25 \%$ sehubungan dengan adanya penanganan kasus yang terlambat.Angka Kematian Ibu di Indonesia pada tahun 2015 adalah 102 kematian per 100.000 kelahiran hidup. Berdasarkan Survei Demografi dan Kesehatan Indonesia (SDKI) tahun 2012, AKI yang berkaitan dengan kehamilan sebesar 359 per 100.000 kelahiran hidup, target pemerintah pada tahun 2015 adalah tercapainya kesejahteraan dan pembangunan masyarakat pada tahun 2015 dengan menurunkan AKI sebesar 3/4 antara tahun 1990 sampai 2015. Angka ini masih cukup jauh dari target yang harus dicapai pada tahun 2015, target ini belum tercapai karena masih banyaknya persalinan yang di tolong oleh tenaga non medis, persalinan yang di tolong oleh bidan sebanyak $(68,6 \%)$, Dokter $(18,5 \%)$, tenaga non kesehatan sebanyak $(11,8 \%)$, kelahiran terjadi tanpa ada penolong sebanyak $(0,8 \%)$ dan $(0,3 \%)$ kelahiran di tolong oleh perawat (Kemenkes RI, 2015).

AKI maternal mengalami fluktuasi selama 3 tahun terakhir yaitu pada tahun 2016 sebanyak 6 kematian ibu dari 25.614 (0,02\%) kelahiran hidup (AKI : 23.42 / $100.000 \mathrm{KH}$ ) 
Dinamika Kesehatan Jurnal Kebidanan dan Keperawatan Vol 11 No. 1 Juli 2020 ( ISSN: 2086-3454 EISSN: 2549-4058) url: http://ojs.dinamikakesehatan.unism.ac.id DOI : https://doi.org/10.33859/dksm.v11i1

Pengaruh Pemberian Kalsium Terhadap Penurunan Tekanan Darah Ibu Hamil Dengan Riwayat Preeklampsi

sedangkan pada 2015 sebanyak 5 kematian ibu dari $25.181(0,01 \%)$ kelahiran hidup AKI : 19,86/100.000 KH). Tahun 2014 sebanyak 5 kematian ibu dari 24.590 (0,02\%) kelahiran hidup (AKI : 20,33/100.000 KH). Upaya yang dilakukan dalam mengantisipasi masalah kematian ibu yaitu melalui peningkatan peran kader Posyandu agar proaktif mendampingi ibu-ibu hamil dalam mendapatkan pelayanan kesehatan (K1-K4) serta penyuluhanpenyuluhan sehingga diharapkan ibu-ibu hamil sadar akan kondisi kesehatannya dan mengutamakan pertolongan persalinan dari Tenaga Kesehatan yang berkompeten (Dokter dan Bidan).

Data dari 5 puskesmas yaitu barabaraya, kassi-kassi, ujung pandang baru,mamajang, dan batua raya di dapatkan bahwa angka kejadian hipertensi masih cukup tinggi, Data dari Puskesmas kassi-kassi sebesar 2,31\% dari 690 ibu hamil, bara-baraya sebesar 2,87\% dari 769 ibu hamil, ujung pandang baru sebesar 3,02\% dari $790 \mathrm{ibu}$ hamil, mamajang sebesar 2,87\% dari $699 \mathrm{ibu}$ hamil dan batua raya sebesar 2,45\% dari 612 ibu hamil, dari 3 tahun terakhir sampai September 2018 rata-rata angka kejadian hipertensi meningkat dari kelima Puskesmas tersebut. di negara berkembang umumnya memiliki asupan kalsium yang rendah, penelitian yang di lakukan di kamerun menunjukkan sebanyak 94,6\% ibu hamil memiliki asupan kalsium inadekuat dengan rata-rata asupan kalsium 493,2 mg/hari, 55\% ibu hamil memiliki asupan kalsium inadekuat dengan rata2 kalsium 493,2 mg hari(Purnasari, Briawan and Dwiriani, 2016)g.

Asupan kalsium yang rendah menyebabkan peningkatan tekanan darah tinggi dengan merangsang pelepasan hormone paratiroid dan atau renin yang mengarah terjadinya peningkatan konsentrasi kalsium intra seluler dalam vaskuler sel otot polos dan mengakibatkan vasokonstriksi. Peranan suplemen kalsium dalam menurunkan gangguan hipertensi dalam kehamilan adalah dengan menurunkan pelepasan kalsium paratiroid dan konsentrasi kalsium intraseluler, akhirnya terjadi penurunan kontraksi otot polos dan peningkatan vasodilatasi (Aamer et al., 2011).

Faktor Mineral dan gizi memainkan peran sebagai salah satu etiologi prediksi hipertensi dalam kehamilan. Beberapa studi melakukan penelitian intake kalsium pada kehamilan normal dan kehamilan dengan komplikasi. Terdapat efek yang signifikan pemberian tablet kalsium dan vitamin D pada ibu hamil terhadap tekanan darah, kadar kalsium dan hasil keluaran pada bayi yang dilahirkan (Wuna dkk., 2016).Studi yang lain didapatkan bahwa tekanan darah pada ibu hamil yang hipertensi setelah konsumsi tablet kalsium terjadi penurunan dengan rerata sistol 4,66 $\mathrm{mmHg}$ dan rerata diastol $6.66 \mathrm{mmHg}$ diikuti juga dengan kadar kalsium pada ibu hipertensi lebih tinggi dengan rerata 0,217 
Dinamika Kesehatan Jurnal Kebidanan dan Keperawatan Vol 11 No. 1 Juli 2020 ( ISSN: 2086-3454 EISSN: 2549-4058)

url: http://ojs.dinamikakesehatan.unism.ac.id DOI : https://doi.org/10.33859/dksm.v11i1

Pengaruh Pemberian Kalsium Terhadap Penurunan Tekanan Darah Ibu Hamil Dengan Riwayat Preeklampsi

$\mathrm{mg} / \mathrm{dl}$ dibandingkan dengan normotensi rerata 0,117 mg/dl (Rahmelia, Diah and Said, 2015)

\section{METODE PENELITIAN}

\section{Desain Penelitian}

Jenis penelitian ini merupakan penelitian kuantitatif observasional. Penelitian ini menggunakan desain quasieksperimental dengan rancangan pre-post test, dalam penelitian ini menggunakan longitudinal study yang bertujuan untuk mengetahui pengaruh pemberian suplemen kalsium pada ibu hamil riwayat preeklampsi.

\section{Populasi dan Sampel}

Populasi dalam penelitian ini sebanyak 30 sampel. Besaran atau ukuran sampel sangat tergantung dari besaran tingkat ketelitian atau kesalahan yang di inginkan peneliti dala penelitian ini untuk menentukan besar sampel peneliti menggunakan estimasi proporsi

$$
\mathrm{n}=\frac{\mathrm{za}^{2} \mathrm{xp}(1-\mathrm{p})}{\mathrm{d}^{2}}
$$

keterangan :

$\mathrm{n} \quad=$ jumlah sampel

za = tingkat kepercayaan $95 \%$

$$
\begin{aligned}
& \mathrm{p} \quad=\text { estimasi proporsi } 5 \%(0,5) \\
& \mathrm{d} \quad=\text { presisi }(0,01 \mathrm{~s} / \mathrm{d} 0,25) \\
& \mathrm{n}=\frac{\mathrm{za}^{2} \times \mathrm{p}(1-\mathrm{p})}{\mathrm{d}^{2}} \\
& \mathrm{n}=1,96^{2} \times \mathrm{p}(0,5) \\
& 0,18^{2} \\
& \mathrm{n}=3,8416 \times 0,25 \\
& 0,03 \overline{24} \\
& \mathrm{n}= \\
& 0,0324 \\
& \mathrm{n}=29,9604 \\
& \hline
\end{aligned}
$$

Jadi besar sampel minimal dalam penelitian ini adalah 30 orang

\section{Pengumpulan Data}

Tekhnik pengumpulan data merupakan cara yang dilakukan untuk memperoleh datadata yang mendukung pencapaian penelitian. Pengumpulan data dilakukan menggunakan data sekunder dan data primer.Data sekunder diperoleh dari catatan Puskesmas yaitu jumlah ibu hamil trimester II dan III. Data primer diperoleh secara langsung dari responden yang dikumpulkan melalui lembar kuesioner untuk mendapatkan data ibu hamil riwayat preeklampsi dan dilakukan pemeriksaan tekanan darah ibu hamil dengan riwayat preeklampsi.

\section{Tekhnik Analisa Data}

Analisis dalam penelitian ini menggunakan uji sesuai tujuan dan skala ukur variabel yaitu Wilcoxon. Hipotesis diterima apabila $\mathrm{p}<\mathrm{a}(0,05)$.

Untuk memudahkan perhitungan pene liti menggunakan komputerisasi program Statistical Package for Social Science (SPSS) for windows versi 24 dengan ketentuan; jika pvalue $<\mathrm{a}(0,05)$ maka menyatakan ada pengaruh pemberian kalsium terhadap tekanan darah ibu hamil riwayat preeklampsi. Pengolahan data dengan menggunakan analisis univariat untuk mengetahui distribusi frekuensi dan analisis bivariate untuk mengetahui perbedaan sebelum dan sesudah perlakuan. Hasil analisisnya ditampilkan dalam bentuk narasi maupun table distribusi frekuensi. 
Dinamika Kesehatan Jurnal Kebidanan dan Keperawatan Vol 11 No. 1 Juli 2020 ( ISSN: 2086-3454 EISSN: 2549-4058) url: http://ojs.dinamikakesehatan.unism.ac.id DOI : https://doi.org/10.33859/dksm.v11i1

Pengaruh Pemberian Kalsium Terhadap Penurunan Tekanan Darah Ibu Hamil Dengan Riwayat Preeklampsi

\section{HASIL}

Tabel 1. Karakteristik Responden Berdasarkan Tekanan Darah Ibu Hamil

\begin{tabular}{ccccccc}
\hline Variabel & \multicolumn{4}{c}{ Hipertensi } & \multicolumn{2}{c}{ Normal } \\
& $\mathrm{N}$ & $\%$ & $\mathrm{~N}$ & $\%$ & $\mathrm{~N}$ & $\%$ \\
\hline Umur & & & & & & \\
$25-29$ & 11 & 36,67 & 4 & 36,36 & 10 & 63,64 \\
$30-35$ & 19 & 63,33 & 9 & 47,37 & 7 & 52,63 \\
Paritas & & & & & & \\
$2-4$ & 28 & 93,33 & 12 & 42,86 & 16 & 57,14 \\
$>4$ & 2 & 6,67 & 1 & 50 & 1 & 50 \\
Trimester & & & & & & \\
II & 23 & 76,67 & 11 & 47,82 & 12 & 52,17 \\
III & 7 & 23,33 & 2 & 27,57 & 5 & 71,43 \\
UK & & & & & & \\
$20-27$ & 22 & 73,33 & 11 & 45,5 & 11 & 45 \\
$28-32$ & 8 & 26,67 & 2 & 37,5 & 6 & 62,5 \\
\hline
\end{tabular}

Berdasarkan data pada Tabel 1 menunjukkan bahwa karakteristik responden berdasarkan tekanan darah di dapatkan umur 25-29 sebanyak 11 orang (36,67\%) dengan tekanan darah hipertensi sebanyak 4 orang $(36,36 \%)$ dan 10 orang $(63,64 \%)$ dengan tekanan darah normal,untuk umur 30-35 tahun di dapatkan sebanyak 19 orang,mengalami hipertensi sebanyak 9orang(47,37\%)dan yang normal sebanyak 7 orang(52,63\%).untuk paritas 2-4 sebanyak 28 orang dengan hipertensi sebanyak 12 orang(42,86\%)normal sebanyak 16 orang $(57,14 \%)$ sedangkan untuk paritas $>4$ sebanyak 2 orang dan memiliki hipertensi sebanyak 1 orang(50\%) dan normal sebanyak 1 orang(50\%), untuk trimester II sebanyak 23 orang(76,67\%) dengan jumlah hipertensi sebanyak 11 orang(47,82\%)dan normal sebanyak 12 orang(52,17\%) trimester III dengan jumlah 7 orang(23,33\%) dengan hipertensi sebanyak 2 orang(27,57\%) dan normal sebanyak 5 orang(71,43\%), untuk umur kehamilan 20-27 sebanyak 22 orang $(73,33 \%)$ dengan hipertensi sebanyak 11 orang $(45,5 \%)$ dan normal sebanyak 11 orang (45\%) dan untuk umur kehamilan 28-34 sebanyak 8 orang dengan hipertensi sebanyak $2(37,5 \%)$ dan normal sebanyak 6 orang $(62,5 \%)$

Tabel 4. Perubahan Tekanan Darah Pada Ibu Hamil Dengan Riwayat Preeklampsi Sebelum dan Setelah Pemberian Kalsium

\begin{tabular}{cccccccc}
\hline \multirow{2}{*}{ Variabel } & \multirow{2}{*}{ N } & \multicolumn{2}{c}{ TD Pre } & \multicolumn{2}{c}{ TD Post } & pValue & \\
& & Mean & SD & Mean & SD & & $p$ Value \\
\hline Hipertensi & & & & & & & \\
& & 146,15 & 10,43 & 118,46 & 14,04 & .000 & $P=$ \\
Sistole & 13 & $\mathbf{8 1 , 5 3}$ & 8,00 & 74,61 & 11,26 & .108 & 0,00 \\
Diastole & & & & & & & \\
Normal & & & & & & &
\end{tabular}

\begin{tabular}{|c|c|c|c|c|c|c|c|}
\hline $\begin{array}{r}\text { Sistole } \\
\text { Diastole }\end{array}$ & 17 & $\begin{array}{c}121,76 \\
82,35\end{array}$ & $\begin{array}{c}10,14 \\
\mathbf{8 , 3 1}\end{array}$ & $\begin{array}{c}112,35 \\
78,24\end{array}$ & $\begin{array}{c}10,32 \\
7,27\end{array}$ & $\begin{array}{l}.009 \\
.150\end{array}$ & $\begin{array}{c}P= \\
0,00\end{array}$ \\
\hline Total & & & 30 & & & & \\
\hline
\end{tabular}
menunjukkan bahwa perubahan tekanan darah sebelum dan setelah di berikan kalsium di dapatkan ibu hamil hipertensi sebanyak 13 orang dengan rata-rata systole pre 146,15 dengan SD 10,43, setelah pemberian kalsium rata-rata TD systole 118,46 dengan SD 14,04 di dapatkan pvalue $=0,000$,rata-rata diastole sebelum pemberian kalsium 81,53 SD 8,00 setelah pemberian kalsium rata-rata diastole menjadi 11,26 dengan $\rho$ value $=0,108$, tekanan darah normal sebanyak 17 orang dengan ratarata systole sebelum pemberian kalsium 121,76 dengan SD 10,14, setelah pemberian kalsium rata- sistolenya menjadi $112,35 \mathrm{SD}$ 10,32 dengan $\rho$ value $=0,009$, rata-rata diastole td normal sebelum pemberian kalsium 82,35, SD 8,31, setelah pemberian kalsium rata-rata 
Dinamika Kesehatan Jurnal Kebidanan dan Keperawatan Vol 11 No. 1 Juli 2020 ( ISSN: 2086-3454 EISSN: 2549-4058) url: http://ojs.dinamikakesehatan.unism.ac.id DOI : https://doi.org/10.33859/dksm.v11i1

Pengaruh Pemberian Kalsium Terhadap Penurunan Tekanan Darah Ibu Hamil Dengan Riwayat Preeklampsi

diastolenya $78,24, \quad$ SD 7,27 dengan pvalue $=0,150$

\section{PEMBAHASAN}

Pada penelitian ini menunjukkan bahwa ibu hamil dengan riwayat preeklampsi lebih banyak terjadi trimester ke 2 yaitu sebanyak 23 orang ibu hamil. Ibu hamil yang terjaring dengan riwayat preeklampsi harus mendapat perhatian lebih oleh pihak terkait terutama tenaga kesehatan, semakin dini jejaring maka semakin cepat ibu hamil mendapat pelayanan yang tepat untuk mengurangi angka kematian ibu dan janin.

Hasil penelitian menunjukkan bahwa ibu hamil dengan riwayat preeklampsi lebih banyak terjadi pada trimester kedua yaitu sebanyak 22 orang ibu hamil, umur kehamilan memiliki kaitan yang erat dengan preeklampsi. Preeklampsi merupakan suatu sindrom spesifik pada kehamilan yang terjadi setelah usia kehamilan 20 minggu, pada wanita sebelumnya normotensi proteinuria hanya timbul setelah 20 minggu.

Hasil penelitian ini adalah paritas $2-$ 4 sebanyak 28 orang dan paritas $>4$ sebanyak 2 orang menunjukkan bahwa preeklampsi kebanyakan terjadi pada paritas 24,Preeklampsi sering terjadi pada primigravida khususnya primigravida muda.

Hasil analisis data tekanan darah ibu hamil menggunakan Uji wilcoxon, pada ibu hamil dengan riwayat preeklampsi sebelum dan setelah pemberian kalsium didapatkan hasil nilai $p$ Value .000 atau $<0,05$, artinya terdapat perbedaan yang signifikan. Dengan demikian disimpulkan bahwa setelah pemberian kalisum selama 8 minggu, terdapat penurunan tekanan darah pada ibu hamil dengan riwayat preeklampsi

Suplemen kalsium menurunkan keadaan hiperparatiroid yang pada akhirnya menurunkan kalsium intraseluler dan tekanan darah. Pada kehamilan aterm, fetus mengambil hampir 30 gram kalsium dari kalsium ibu, yang diambil dari tulang ibu, apabila asupan kalsium ibu rendah. Kalsium yang rendah penyebab tekanan darah tinggi yang dipicu oleh pelepasan hormon paratiroid atau renin yang menyebabkan peningkatan kalsium intraseluler pada vascular smooth muscle dan memicu vasokontriksi (Bahar \&Mulya, 2014). Aksi dari suplemen kalsium menurunkan pelepasan paratiroid dan intraseluler kalsium dan menyebabkan penurunan kontraktilitas smooth muscle. Dengan mekanisme yang sama suplemen kalsium juga menurunkan kontraksi smooth muscle uterus dan mencegah kelahiran preterm serta persalinan.

Beberapa studi menunjukkan kadar plasma $\mathrm{Ca} 2+$ menurun sedikit pada kehamilan normal dan menurun tajam pada preeklamsia. PTH dan kalsitonin tidak banyak berubah dari kadar nonpregnant, dan meningkat dan menurun dalam ekskresi renal $\mathrm{Ca} 2+$ pada kehamilan normal dan preeklamsia. Studi lain menyebutkan tidak ada perbedaan pada kalsitonin pada umur kehamilan trimester 
Dinamika Kesehatan Jurnal Kebidanan dan Keperawatan Vol 11 No. 1 Juli 2020 ( ISSN: 2086-3454 EISSN: 2549-4058) url: http://ojs.dinamikakesehatan.unism.ac.id DOI : https://doi.org/10.33859/dksm.v11i1

Pengaruh Pemberian Kalsium Terhadap Penurunan Tekanan Darah Ibu Hamil Dengan Riwayat Preeklampsi

ketiga pada preeklamsia dan kehamilan normal.

Asumsi peneliti bahwa Suplemen kalsium memainkan peranan yang penting dalam pencegahan hipertensi dalam kehamilan yang dapat memicu terjadinya preeklmpsia dengan menjaga kadar ion kalsium dalam rentang (range) fisiologis. Hal ini menunjukkan bahwa menjaga kadar kalsium sangat penting dalam sintesis substansi vasoaktif seperti prostasiklin dan nitric oxide pada endotel dalam mempertahankan fungsi endotel normal dan menurunkan tekanan darah.

\section{KESIMPULAN DAN SARAN}

Berdasarkan hasil penelitian yang di lakukan, terlihat bahwa terdapat penurunan tekanan darah pada ibu hamil dengan riwayat preeclampsia setelah pemberian kalsium, pada tekanan darah memiliki pengaruh yang sangat signifikan setelah pemberian kalsium. Bagi peneliti selanjutnya dapat mengembangkan penelitian ini dengan melakukan pemeriksaan kadar kalium dan klorida pada ibu hamil dengan riwayat preeklampsi

\section{DAFTAR PUSTAKA}

Aamer I., Afsan J., \&Julfiqar A. (2011). Role of calcium supplementation during pregnancy in reducing risk of developing gestational hypertensive disorders: a metaanalysis of studies from developing countries. BMC public health 11. suppl 3. S18.
Bahar H.\&Mulya F. M. (2014). Hubungan Asupan Suplemen Kalsium Pada Ibu Hamil Dengan Panjang Bayi Saat Lahir Di Wilayah Cengkareng Jakarta Barat. Nutrire Diaita Volume 6 Nomor 2

Febriana E dkk.(2017).Hubungan asupan natrium,kalsium dan magnesium dengan tekanan darah ibu hamil trimester II dan III.JKM volume 5, nomor 4 oktober 2017 (ISSN:23563346)

Helga. (2016). perbedaan rerata rasio kalsium magnesium dan rerata rasio natrium kalium serum, Obgin Emas

Kartika D. (2016). Warning! Ibu Hamil. Surakarta : Ziyad Visi Media

Kemenkes RI. (2015). Prevalensi Ibu hamil Di Indonesia. Jakarta : Badan Litbangkes Kemenkes RI

Rismawati. (2012).Fisiologi dan gangguan keseimbangan natrium,kalium,klorida serta pemeriksaan laboratorium, jurnal kesehatan andalas

Purnasari, G., Briawan, D. and Dwiriani, C. M. (2016) 'Kepatuhan Konsumsi Suplemen Kalsium Serta Hubungannya Dengan Tingkat Kecukupan Kalsium Pada Ibu Hamil Di Kabupaten Jember', Jurnal Kesehatan Reproduksi, 7(2), pp. 8393. 10.22435/kespro.v7i2.4968.83-93.

Rahmelia, D., Diah, A. and Said, I. (2015) 'Analisis Kadar Kalium (K) Dan Kalsium (Ca) Dalam Kulit Dan Daging Buah Terung Kopek Ungu (Solanum melongena) Asal Desa Nupa Bomba Kecamatan Tanantovea Kabupaten Donggala', Jurnal Akademika Kimia, 4(3), pp. 143-148. 
Dinamika Kesehatan Jurnal Kebidanan dan Keperawatan Vol 11 No. 1 Juli 2020 ( ISSN: 2086-3454 EISSN: 2549-4058)

url: http://ojs.dinamikakesehatan.unism.ac.id DOI : https://doi.org/10.33859/dksm.v11i1

Pengaruh Pemberian Kalsium Terhadap Penurunan Tekanan Darah Ibu Hamil Dengan Riwayat Preeklampsi

WHO.(2013). a global brief on hypertension, World Health OrganizationInternational Society of Hypertension statement of Management of Hypertension

Wuna W. dkk. (2016). Efek pemberian suplemen kalsium dan vitamin D pada ibu hamil hipertensi terhadap outcome kehamilan di Puskesmas Kota Kendari. Makassar: Universitas Hasanuddin. 